\title{
The Failure of Implementation Broadcasting Regulations in Indonesia-Malaysia Border Region: Case Study on Free-to-air Television in Meranti Regency, Riau Province - Indonesia
}

\author{
HARRY SETIAWAN \\ SITI KARLINAH \\ DADANG RAHMAT HIDAYAT \\ Universitas Padjadjaran, Indonesia \\ YULIANDRE DARWIS \\ Universitas Andalas, Indonesia
}

\begin{abstract}
Border residents in Meranti Regency still love Malaysian free to air television broadcasts. The broadcasting regulation stipulates that broadcasters must provide free to air access to foster a love of Indonesian television broadcasts and a spirit of nationalism for all levels of society. However, the reality in the field is inversely proportional. An important point that questioned in this research is how the implementation of broadcasting regulations governing equality of access to information and containers of cultural expression in free to air broadcasts for all Indonesian people, especially in border areas. This study aims to reveal the extent of the application of broadcasting regulations in the border region in the context of free to air broadcasts and cultural expression containers in free to air broadcasts. Social action media studies used as an analytical tool to reveal that access and broadcasting infrastructure are a necessity for reaching viewers. The program of the choice model is another analytical tool in uncovering the motives for selecting free to air broadcasts that are loved by border society. The case study method used to find data from the field of a single case that is the implementation of free to air broadcasting regulations in the Indonesian border region of Malaysia. As a result, broadcasting regulations are considered unsuccessful in the context of free to air in the border regions, and the expression of Malay culture has no place on Indonesian television, which in turn, the Malay cultural preference filled with free to air Malaysian broadcasts.
\end{abstract}

Keyword: Broadcasting, free-to-air, audience, border society, culture.

\section{INTRODUCTION}

Riau Province is one of the provinces that is dealing directly with Malaysia. Geographically, Riau Province has six districts bordering Malaysia, namely Siak Regency, Rokan Hilir Regency, Pelalawan Regency, Meranti Regency, Bengkalis Regency, and Dumai City. The regency which borders with Malaysia is Meranti Regency which also located on the eastern coast of Sumatra, with a coastline that borders Malaysia and Singapore and includes in the Indonesia-MalaysiaSingapore Growth Triangle.

There are three large islands in the Meranti Regency which face directly to Malaysia, namely Tebing Tinggi Island, Rangsang Island, and Merbau Island. The stimulant island experienced an expansion in 2016, which became an administrative region with two subdistricts, namely the excitement of the west and the stimulation of the coast. The expansion aims to accelerate village development even though the Subdistrict of Rangsang Pesisir is still the district with the most impoverished population in the Meranti Regency. Apart from working as fishermen, many residents from the border work as part-time foreign workers in 
Malaysia. Poverty in the border society centered on poverty in livelihood resources, weak employment, and poor access to Indonesian information through broadcast media.

Broadcast infrastructure gap in the Indonesia Malaysia border region in Meranti district, which until now still faces difficulties in accessing Indonesian information through free-to-air broadcasts that have occurred over the past 25 years. Until which makes Malaysian free-to-air television broadcasts more desirable because broadcasting infrastructure and power, Malaysian television broadcasts are better received using a terrestrial antenna.

Free-to-air broadcasts are the only affordable information access for border residents. It makes the public habit to search for and receive information only from television because television can provide entertainment for free (Strangelove, 2015). Moreover, television viewing activities often become routine daily that can do starting from the television turned on until turned off again (Wonneberger, Schoenbach \& van Meurs, 2009).

Television presents a large selection of broadcast programs in free-to-air services so that the adaptation of viewers to broadcast programs continues to change even when the viewers watch (Wonneberger et al., 2009). The differentiation of broadcast programs that presented free-to-air broadcasts can make the top choice for viewers, and not a few of them are careful in choosing transmissions based on their motives and feelings (Brosius, Wober, \& Weimann, 1992).

Furthermore, access to free-to-air broadcasts also plays an essential role in influencing the viewer's decisions. The reality of border residents tends to prefer Malaysian television broadcasts over Indonesian television for some entertainment broadcast contexts because Indonesian television shows are dominated by soap operas that are not culturally relevant Malay and not educating. After all, it gives access to imitators of shows that will continue to remain anonymous (Strangelove, 2015). Also, aspects of industrialism currently shared by all Indonesian television stations where all aspects of production are standardized (Holmes, 2005) so that the community does not widely have a choice of shows, broadcast characters, and entertainment (Walsh, 2015).

The Indonesian broadcasting regulations, as stipulated in the Broadcasting Law No. 32 of 2002 mandates through the Indonesian Broadcasting Commission (Presiden Republik Indonesia, 2002), to build engagement broadcasting stakeholders. Furthermore, focus on updating infrastructure in the regions, which subsequently establishes an agreement with the district government to develop a Local Public Broadcasting Institution (Presiden Republik Indonesia, 2005) to provide access to information for all citizens, especially those living in border areas. It is not enough to just that, the Indonesian broadcasting commission and its marriage in the regions, namely the Indonesian broadcasting commission in Riau, are building the construction of a particular transmitting station in the border area used by TVRI RiauKepri.

There are still many Indonesia-Malaysia border areas in Riau Province with blank spot status, and none of Indonesia's commercial broadcasting infrastructure airs there and serves the border community. And then, of course, creates problems for Indonesia because many of the border residents enjoy foreign television broadcasts, especially Malaysia, which has the same ethnic group, Malay.

Weaknesses in the practice of broadcasting regulations that demand equal distribution of broadcasting infrastructure and the lack of equal access to free information provided by the state are sources of problems in this research case study, especially in the border area in Meranti Regency in Riau Province. Geographical proximity, pleasant transmit 
power for some Malaysian free-to-air broadcasts, can penetrate the UHF (Ultra High Frequency) range and are well received by border society. A close cultural relationship between the Malays includes being a separate reason for more Malaysian broadcasts than Indonesian broadcasts on the border region.

The closeness of Malay culture is indeed very fluid in Indonesia. However, there are several different linguistic features, including those that make Malaysian television shows in demand (Dahlan, 2015) Indonesian audiences, especially in border areas, Upin and Ipin animated series as examples. The portrait of actual cultural reality depicted in the animated series Upin and Ipin becomes a reality of a new and good spectacle for all ages (Nur Salawati \& Hanita, 2013). However, Malaysia is also a portrait of multiple cultural realities present in its citizens' lives so that the perceptions current at the viewer can influence his behavior (Peiser \& Peter, 2000).

Other conditions, the high costs incurred by border society to enjoy Indonesian freeto-air television broadcasts, are not another obstacle for border society and enjoy Indonesian shows using satellite TV. Which requires a large amount of money from Indonesian television broadcasts that violate broadcasting regulations and get sanctions such as containing pornographic elements, verbal and nonverbal violence, urban hedonism that not well presented in television shows (Komisi Penyiaran Indonesia, 2012; Presiden Republik Indonesia, 2002).

Weak implementation of broadcasting regulations in Indonesia in border areas and minimal broadcast infrastructure so that access to information and entertainment of border society is served by free-to-air television broadcasts of Malaysia which finally: a vital point that questioned in this research is how the implementation of broadcasting regulations governing equality of access to information and containers of cultural expression in free to air broadcasts for all Indonesian people, especially in border areas. This study aims to reveal the extent of the application of broadcasting regulations in the border region in the context of free to air broadcasts and cultural expression containers in free to air broadcasts.

\section{LITERATURE REVIEW}

Research on the issue of Indonesian Malaysian border broadcasting has conducted several times (Andung, Sjuchro, Liliweri, \& Hadisiwi, 2018b, 2018a; Prasojo, 2013; Yusuf, 2017). Prasojo (2013) who portrayed the dynamics of the ethnic life of the "Iban" inhabiting the border region in West Kalimantan despite being in an era of globalization, the media, and technology and being on the boundaries of two countries. The ethnic "Iban" still highlighted the right side of that is prioritizing courtesy, friendliness, and open to migrants; even though they are on national borders, they can quickly exit and enter two countries. Access to information through Indonesian free-to-air television is necessary because Malaysian free-toair television access is more comfortable for Malaysian television broadcasting infrastructure is better and more reliable there.

In contrast to Prasojo (2013) and Yusuf (2017) conduct radio research as a messenger from the border to the middle of civilization in several Indonesia-Malaysia border areas in Etikong-West Kalimantan (Indonesia) and Sarawak (Malaysia), Batam-Riau Islands (Indonesia) and Singapore. Which produced an approach that border issues could be brought to the center of civilization by utilizing community radio. Community radio is one of the best ways to convey messages in border areas because $82.36 \%$ of border society still use radio as their information and entertainment media. 
Furthermore, research conducted by Andung et al. (2018a), found that television has a central position in society. Television ownership is one of the determinants of comfort. The results of this study are: First, television considered to have economic value as a reference in launching border economic and business activities. Second, television saw as able to build the amount of national pride. Third, the existence of physical television is a symbol of comfort for the people of Napan Village. Fourth, the value of social relations created through long talk about television programs in daily social interactions. Finally, watching television is a mandatory ritual where the television agenda becomes the community agenda (Andung et al., 2018a).

The broadcasting infrastructure in question is a service and technology that supports free-to-air broadcasts, a measure of human civilization, especially in the border region (Andung et al., 2018a). Television is a symbol that controls the community's social status, where access will also broadcast become the main thing to build values in society including Nationalism (Andung et al., 2018b).

Ease of access in broadcasting technology takes another essential position to influence viewer's decisions in enjoying their television. The theoretical framework starts from the social studies media theory (Schoening \& Anderson, 1995) which is the opposite view of media use and gratification (Renckstorf, McQuail, \& Jankowski, 1996). This one implied by the assumptions of the theory that built where media content has no essential meaning, so it does not explain the use of media or exposure to media messages to the public. Nevertheless, rather the assumption on the theory that humans construct the meaning of media and text technology within a framework of collective understanding (Littlejhon \& Foss, 2009; Schoening \& Anderson, 1995). Viewers collectively parse symbols, texts in television shows (Jensen, 1990) so that the use of broadcast technology in this case television has concrete implications in the process of decomposing symbols and texts that become a reference in social action.

The theory of social action media studies is a theory that views the perspective of social actions carried out individually or in groups (Castelfranchi, 1998). These actions refer to the activities of individuals in the group. The theory of social action media studies looks at the phenomenon of communication not on media content so that media content has no essential meaning, does not explain the use of media or media effects originating from media exposure. This theory starts the assumption that humans construct the meaning of media and text technology within a framework of collective understanding (Littlejhon \& Foss, 2009; Schoening \& Anderson, 1995).

Gerard Schoenring and James Anderson (1995) make clear boundaries on social action media research where meaning not contained from the message but results from an interpretive process in the audience (Littlejhon \& Foss, 2009). The purpose of media messages and programs not to determined passively but actively produced by the audience, meaning they do something with what they see and read. The meaning of a program or message is never self-determined but communal.

Implementation of broadcasting regulation as a media study of social community action constructed in this research is the equal access to information and entertainment through Indonesian free-to-air television broadcasting as an action in implementing broadcasting regulations that still apply in Indonesia. Next, the Malay cultural preference present on the Indonesian free-to-air television program became a conception of cultural 
expression in the Indonesia-Malaysia border community in determining its programs and television stations.

The determination of cooperative programs is the subject of the choice of program model (Webster \& Wakshlag, 1983; Wonneberger et al., 2009) which presents the pretension of a program on a television station based on the best match between the preferences and availability of the program on the television station. Then the viewers also choose a program that is beneficial for him.

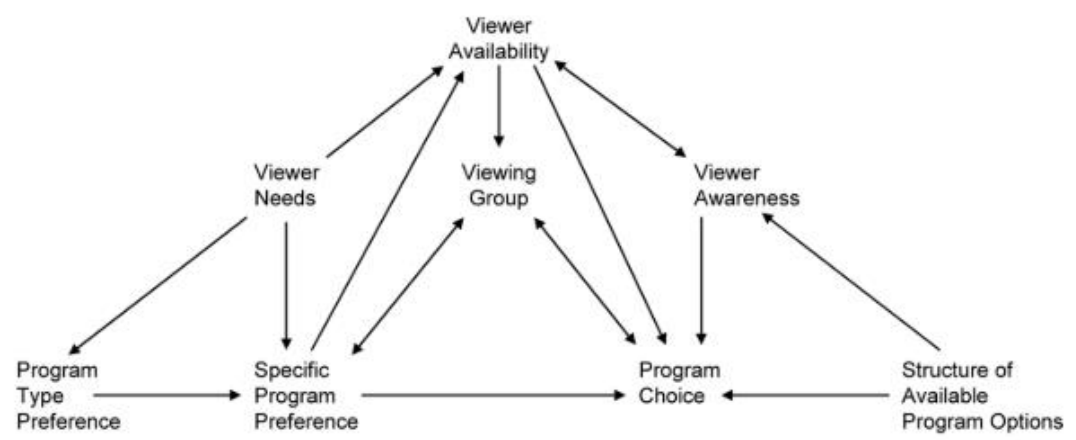

Figure 1: The model of program choice by Webster \& Wakshlag Source: (Webster \& Wakshlag, 1983)

The program choice model by Webster and Wakshlag (1983) illustrates the reason for the viewer choosing his program. He based on his needs and preferences presented on the show so that the ability to be able to reach the show becomes an ultimate reference of the choice of television station broadcast programs in his privacy and social space (Wonneberger et al., 2009). Furthermore, to reach the broadcasts that he has determined, the role of access and supporting infrastructure is the next reason. In this case, the broadcasting infrastructure, especially in the Indonesian border region of Malaysia, in the meranti district.

The choice of television program or station depends on the use of media technology to be able to present varied content that forms an accessible audience entity so that it is related to mass media and broadcasts capable of offering new social realities for viewers and viewers (Bagozzi \& Dholakia, 2002; Jensen, 1990). Malay cultural preferences that are absent on Indonesian television broadcasts were all broadcast cultural contexts on Indonesian television. They dominated by Betawi, Sundanese, and Javanese cultures, which generally tend to create patterns of cultural domination in Indonesian free-to-air programs as a whole (Shugart, 2007).

Broadcasting regulations in Indonesia should be able to be applied as a whole and accommodate all the public's information needs in general and in particular border areas. The Indonesian, which was supposed to be a gateway to public information, was deformed because the broadcasting infrastructure was not present in the border region. The similarity of language used in the daily lives of border society, namely Melayu or Malay, becomes a vital factor in the viewing behavior of border society where most of Malaysia's free-to-air broadcasts received by border residents use Malay. Moreover, where language and culture are the codes of close communication (Ellis \& Maoz, 2003).

The long history of the media regulatory society has been passed before the current media regulation and controlled by the government (Setianto, 2015). During the authoritarian period (1974-1998), Indonesia only had two electronic mass media, namely Radio Republik Indonesia (RRI) and Televisi Republik Indonesia (TVRI), broadcast permits. The regime of 
President Suharto entirely controlled it for the benefit of government publications (Morissan, 2019). During the Reformation period, freedom of expression and the growth of the broadcasting industry in Indonesia began in 1999, and up to now, no less than 14 commercial television stations are operating in Indonesia. However, none of Indonesia's free to air broadcasts can be accepted to accommodate the information needs of border communities.

Before the reformation in Indonesia, the television industry in Malaysia has also developed until now. Nevertheless, it still gives an essential role to Malay culture in every content of its broadcast even though the broadcast program is a copycat broadcast from abroad (Juliana, 2010) so that the identity and characteristics of Malay culture are still present. In every broadcast and it is of interest to residents of the Indonesian-Malaysian border.

The identity constructed in free broadcasts for Indonesian broadcasts is different from those for Malaysian broadcasts. Border communities well receive the Malay culture that is shown by free television in Malaysia, even for most Indonesians. For example, the animated series Upin and Ipin that are produced in Malaysia and shown on free to air Indonesia through MNC TV (MNC Group). Social construction as a cultural identity in shows Upin and Ipin built by through symbols and language in the content (Abdussalam \& Wahyudi, 2016), so that the interactions that occur between characters build their own cultural identities.

The face of Malaysia's free broadcast, although it is often haunted by ranking ratings and shares, of course, affect revenue from advertising. Television industry workers in Malaysia retain their creative autonomy (Nur Kareelawati \& Ahmad Fadilah, 2018). The position of Malaysian free to air broadcasts continues to present shows to fulfil the needs of viewers. Still, it maintains cultural entities that often appear in the reality of public viewing, which of course are consumed and in demand by border communities.

\section{METHODOLOGY}

This research uses a social constructivism paradigm that often combined with interpretivism, where interpretive views are grounded in the assumption that the social reality picture of empiricists omits something essential namely general meanings, intersubjective, as well as ways to manifest actions in society expressed in language and descriptions that shape institutions and practices (Denzin \& Lincoln, 2009).

Researchers believe the philosophical assumptions built in this study are an inseparable part of the epistemological question, that is how the implementation of broadcasting regulations and cultural expression in Indonesian is free to air television broadcasts, which will be answered immediately through the research approach (Setiawan, 2019)

The qualitative approach in this research uses a case study research method (Awazu, Barakat, Chevaller, \& Ichikawa, 1989). That case study research includes the study of a case in real life which in this research activity will explore real-life, contemporary limited systems (cases) through data collection involving various sources of the information quoted from interviews, observations, and documentation (Bungin, 2011; Kriyantono, 2008; Sugiyono, 2011; Yin, 2003). Moreover, report on case descriptions in a single case study of free-to-air television broadcasts Malaysia in the Indonesia-Malaysia border region.

William Goode and Paul Hatt (1952) in (Denzin \& Giardina, 2010; Denzin \& Lincoln, 2009) said the case to investigate must be in a framed position (boundedness), and patterns of system behaviour. That are crucial factors in understanding the case what has studied must 
also be well-identified, and the free to water service used by the community is the frame of this study.

Observation became a natural preliminary study to collect data conducted in this study in September - December 2019 and the conduct of interviews and document referrals carried out in December 2019 - February 2020. (Yin, 2003) presents guidelines for the determination of informants in case study research based on individuals related to the case under study, namely policymakers, practitioners, and colleagues as layers of society. Here are the informant data tables in this study.

Table 1: Research Informant

\begin{tabular}{|c|c|c|}
\hline No & Nama & Detail \\
\hline 1 & Irwan Nasir & Regent of Meranti District \\
\hline 2 & Suardi Camong & $\begin{array}{l}\text { Head of Production Division TVRI Riau } \\
\text { Kepri }\end{array}$ \\
\hline 3 & Falzan Surahman & $\begin{array}{c}\text { Chairperson of the Riau Regional } \\
\text { Indonesian Broadcasting Commission }\end{array}$ \\
\hline 4 & Hisam Setiawan & $\begin{array}{c}\text { Deputy Chairperson of the Riau } \\
\text { Regional Indonesian Broadcasting } \\
\text { Commission }\end{array}$ \\
\hline 5 & Datuk Seri H. Al Azhar & $\begin{array}{c}\text { Chairperson of the Malay Customary } \\
\text { Institution of the Riau Traditional } \\
\text { Council }\end{array}$ \\
\hline 6 & Hendri & Local People \\
\hline 7 & Adam & Local People \\
\hline
\end{tabular}

Table 2: Research Reference Documents

\begin{tabular}{ccc}
\hline No & Reference & Author's \\
\hline 1 & Broadcasting Law No. 32/2002 & $\begin{array}{c}\text { Government of the Republic of } \\
\text { Indonesia }\end{array}$ \\
2 & $\begin{array}{c}\text { Government Regulation No. 5/2005 } \\
\text { about local public broadcasting } \\
\text { institutions }\end{array}$ & $\begin{array}{c}\text { Government of the Republic of } \\
\text { Indonesia }\end{array}$ \\
& $\begin{array}{c}\text { Broadcasting Behavior Guidelines and } \\
\text { Standards for Broadcast Programs }\end{array}$ & Indonesian Broadcasting Commission \\
\hline
\end{tabular}

\section{RESULT AND DISCUSSION}

Nationalism, Something Grey in Impressions Indonesian Television Broadcasting Law No. 32 of 2002 has the spirit of organizing broadcasting evenly in all regions of Indonesia as stipulated in article 3 which is mandated,

Broadcasting held to strengthen national integration, foster the character and identity of a faithful and pious nation, educate the nation's life, and advance public welfare, in the context of building an independent, democratic, just and prosperous society, and fostering Indonesian broadcasting.

Furthermore, to build national integration in clause 14 of the broadcast regulation, No. 32 of 2002 is grouped in the classification of the broadcasting service area. which divided into four types of organizers, namely Public Broadcasting Institutions, Private Broadcasting Institutions, Community Broadcasting Institutions, and Subscribed Broadcasting Institutions. So, Indonesian people have all rights to obtain appropriate and correct information which the 
human rights and broadcasting regulations are regulated and become the duties and obligations of the Indonesian Broadcasting Commission (Presiden Republik Indonesia, 2002).

In fact, in the Indonesia-Malaysia border region in Riau Province, especially the Meranti Regency and its outer islands are experiencing infrastructure imbalances. The absence of Indonesian broadcasters in all aspects harms border residents. In the case of Jemur Island, Rokan Hilir Regency which is one of the Indonesia-Malaysia border regions, a resource person who did not want to name as a politician, stated that:

Let alone Jemur Island, One District of Rokan Hilir, please take this part of Malaysia.

While responding to the issue, many other regions in Indonesia voiced "ganyang Malaysia" or "destroy Malaysia." However, the reality was different for some Indonesians in the Border Region in Riau Province. The same cultural fact as Malaysia, that is, Malay made the people of Riau Province undisturbed and responded to the issue as a big problem.

The Malay ethnic group that inhabits many islands in the Meranti Regency has been present for centuries and has a long history with Malaysia as a single-family. Al Azhar, Chair of the Customary Assembly of the Malay Customary Institution (Lembaga Adat Melayu), explained that the cultures present on Indonesian television never paid attention to Malay culture.

For years, Meranti people have interacted and absorbed Malay cultural activities from Malaysia. Culturally, because the Selat Panjang is in the Malacca Strait region and Indonesia is not present there (Interview: Al Azhar, 2019).

The absence of Indonesia in border areas, especially in access to information through television, makes cultural interaction with Malay Malaysia, a prime position for border society. In the last 25 years, border residents only have access to information through Malaysian broadcast media.

Table 3: Border Broadcast Monitoring.

\begin{tabular}{|c|c|c|c|c|c|c|c|c|}
\hline NO & TIME & BAND & (MHz) & $\begin{array}{c}\text { STATION } \\
\text { ID }\end{array}$ & LOCATION & $\begin{array}{c}\text { SIGNAL } \\
\text { STRENGT } \\
\text { H }\end{array}$ & LEVEL & $\begin{array}{l}\text { MEASUREMENT } \\
\text { POINT }\end{array}$ \\
\hline 1 & 2 & 3 & 4 & 5 & 6 & 7 & 8 & 9 \\
\hline 1 & & & 229.750 & & Malaysia & 14,5 & $-84,27$ & \\
\hline 2 & & & 476.750 & & Malaysia & 19,5 & $-91,63$ & \\
\hline 3 & & & 492.750 & RTV & $\begin{array}{c}\text { Dumai - } \\
\text { Indonesia }\end{array}$ & 30,1 & $-80,54$ & \\
\hline 4 & 09 AM- & & 524.750 & & Malaysia & 23,7 & $-91,78$ & $N: 01^{\circ} 41^{\prime} 42,6^{\prime \prime}$ \\
\hline 5 & 06 PM & VHF & 532.750 & & Malaysia & 21,5 & $-92,65$ & E: $101^{\circ} 24^{\prime} 53,2^{\prime \prime}$ \\
\hline 6 & & & 556.750 & & Malaysia & 20,8 & $-75,34$ & \\
\hline 7 & & & 588.750 & & Malaysia & 24,6 & $-75,34$ & \\
\hline 8 & & & 604.750 & & Malaysia & 27,8 & $-75,34$ & \\
\hline 9 & & & 644.750 & & Malaysia & 42,1 & $-75,34$ & \\
\hline 10 & & & 692.750 & & Malaysia & 40,5 & $-75,34$ & \\
\hline
\end{tabular}




\begin{tabular}{|c|c|c|c|c|c|c|c|c|}
\hline NO & TIME & BAND & (MHz) & $\begin{array}{l}\text { STATION } \\
\text { ID }\end{array}$ & LOCATION & $\begin{array}{c}\text { SIGNAL } \\
\text { STRENGTH }\end{array}$ & LEVEL & $\begin{array}{c}\text { MEASUREMENT } \\
\text { POINT }\end{array}$ \\
\hline 1 & 2 & 3 & 4 & 5 & 6 & 7 & 8 & 9 \\
\hline 1 & \multirow{11}{*}{$\begin{array}{l}09 \text { AM- } \\
03 \text { PM }\end{array}$} & VHF & 194.750 & - & Malaysia & 14,5 & $-75,61$ & \multirow{11}{*}{$\begin{array}{l}N: 01^{\circ} 33^{\prime} 44,9^{\prime \prime} \\
E: 102^{\circ} 14^{\prime} 54,5^{\prime \prime}\end{array}$} \\
\hline 1 & & & 476.750 & \multirow[t]{3}{*}{ TV3 } & Malaysia & 19,5 & $-91,63$ & \\
\hline 2 & & & 492.750 & & Malaysia & 30,1 & $-85,54$ & \\
\hline 3 & & & 532.750 & & Malaysia & 78,5 & $-54,31$ & \\
\hline 4 & & & 556.750 & \multirow[t]{3}{*}{ RTM } & Malaysia & 40,8 & $-79,34$ & \\
\hline 5 & & & 588.750 & & Malaysia & 78,6 & $-57,40$ & \\
\hline 6 & & UHF & 596.750 & & Malaysia & 32,3 & $-75,31$ & \\
\hline 7 & & & 604.750 & $\begin{array}{l}\text { Metro } \\
\text { TV }\end{array}$ & $\begin{array}{l}\text { Bengkalis - } \\
\text { Indonesia }\end{array}$ & 45,8 & $-62,34$ & \\
\hline 8 & & & 612.750 & & Malaysia & 45.1 & $-78,31$ & \\
\hline 9 & & & 628.750 & & Malaysia & 40,3 & $-79,33$ & \\
\hline 10 & & & 692.750 & & Malaysia & 30,5 & 81,73 & \\
\hline
\end{tabular}

The two tables above show that in the broadcasting frequency spectrum in the Indonesian territory in Bengkalis and Meranti regency, it should be filled by Indonesian television stations regulated in broadcasting law no 32 of 2002 (Presiden Republik Indonesia, 2002), which requires equal access to free information for the public.

In terms of meeting the viewers' needs in the model proposed (Webster \& Wakshlag, 1983; Wonneberger et al., 2009), the absence of free-to-air television infrastructure in the Indonesian border region of Malaysia in the Meranti Regency can be a challenge in positioning the Nationalism of border society.

Do not ask Nationalism for us, we do not need it, what we need is food, our stomachs are full, and our information needs to be met. Regardless who meets us does not care (Interview: Irwan, 2020).

The regent of Meranti District, Irwan Nasir, who has served for two periods (20102015 \& 2015-2020), stated that the people's Nationalism could not be positioned from the will and subject to the state ideology. However, the people's Nationalism is in the smallest aspects of their social sphere, namely the fulfilment of basic needs and access to information.

According to him, television is one of the people's primary needs. So far, because of economic access in terms of trading activities, and the scope of business people who are fishermen do need information related to Malaysia that they often watch through Malaysian television that they can access. Indonesian broadcasting becomes a second choice for its people, urban hedonism, and the dominance of Javanese, Betawi, and Sundanese culture that are familiar to urban society that present friction of Nationalism for their people in Meranti.

Nationalism is in Jakarta, their lives are happy, access everywhere is easy, cheap goods, good transportation. While we are here, there are still many of my people who have never seen a paved road! (Interview: Irwan, 2020).

Finally, the viewer's awareness of Indonesian television broadcasts contents is no longer the main thing because preferences for the need for access to information in free-toair services have met by Malaysian television. 
Furthermore, Al Azhar saw the political change in the mention of an archipelago that was once called an outermost island, which has the connotation of being left behind. He changed to the foremost archipelago area, but according to him, the implementation of the frontier island's concept had not felt by border residents.

I do not doubt the nationalism of border residents, but caring for nationalism is not what Indonesia does (Interview: Al Azhar, 2019).

According to Al Azhar, Indonesian television that is not present in the border region is proof that Nationalism is not present in Indonesian television broadcasts. The contents of television broadcasts in Indonesia regulated in Broadcasting Law No. 32 of 2002 article 36 paragraph 1 regulating that:

The contents of the broadcast must contain information, entertainment, and benefits for the formation of intellect, character, morals, progress, the strength of the nation, maintaining unity and unity, and practising the values of Indonesian religion and culture.

What happens daily is that many of Indonesia's television broadcasts do not contain Malay cultural values, especially the Malay Archipelago, so Malay cultural experiments that predominantly appear in Malaysian free-to-air border society more accept media broadcasts.

Televisi Republik Indonesia (TVRI), also regulated in broadcasting regulations as the only public broadcasting institution owned by Indonesia, which is, makes a minor contribution in strengthening the Nationalism of border society.

TVRI Riau Kepri is ready, and we are ready for digital broadcasting even for border areas such as Meranti, Siak, Dumai, Bengkalis, we have prepared a digital transmitter. However, the tugging of regulations related to digitalization has become a particular obstacle for the distribution of TVRI broadcasts to all regions of Indonesia, especially the border regions (Interview: Suardi, 2020).

Digital broadcasting that is still not regulated in Indonesia's broadcasting regulations contributes to other problems in terms of access to free-to-air broadcasts in Indonesia. So that the free-to-air broadcasts of Malaysia that have broadcasted digitally and with full power on the transmitter transmission system again make border society have no choice to switch to Indonesian broadcasts.

Several times the Indonesia-Malaysia bilateral relations heather up and the Malay culture considered synonymous with Malaysia so that it does not get a place on Indonesian free-to-air broadcasts. Malay, as a nation in historical fact, says that the relations of many Indonesia-Malaysia border areas, namely the islands in Sumatra and Kalimantan, are part of a long history with Malacca, Johor, Sarawak, Riau Lingga, and Siak. 
Once we make a consensus, join Indonesia since colonial times and finally become independent, Malay becomes something that narrowed down to just ethnicity. Our relationship with the Malacca peninsula becomes just a cultural relationship (Interview: Al Azhar, 2019).

There is make a cultural expression of border society the same as Malaysian culture. Which in many Indonesian free-to-air shows, Malay cultural expressions have no place so that many of the border society in Meranti regency enjoy Malaysian shows because they accommodate Malay cultural expressions.

For example, in a talent search show on Indonesian television, one of the judges was the Malay dangdut singer, lyeth Bustami, known as the singer "Laksamana Raja di Laut." lyeth, whose profession uses Malay, and when giving comments to participants using Malay, but lyeth considered promoting Malaysia on Indonesian television.

We from the Malay traditional institute did not remain silent in responding to the problem by sending an official letter to the television station stating that the language used by lyeth was purely Indonesian Malay.

The Malay language used by lyeth is the everyday language of the Malay people in Indonesia. We from Lembaga Adat Melayu Riau have never complained if Sundanese cultural expressions, Betawi, Javanese in the name of Indonesia, but why if lyeth using the Malay Language is a problem (Interview: Al Azhar, 2019)

Nationalism is a grey area in border society because they are always busy with crossethnic trading activities. Even not a few of them carry out trading activities in Malaysia so that access to information from Malaysia's free-to-air television broadcasts can be a choice in their daily activities.

There Is No Free-To-Air Broadcasting Infrastructure in The Border Region

The broadcast infrastructure that is not available in border areas is expensive for border residents to enjoy. So, not a few of the border residents in the Meranti Regency struggle to enjoy free-to-air broadcasts in Indonesia. Television has become a source of entertainment for many border residents to meet the limitations of access, infrastructure, and insufficient electricity supply, and it seems unable to stop it.

As a social action, researchers found that communal border society is trying to access Indonesian free-to-air broadcasts. They were finally divided into three broadcasting technologies used, that is terrestrial antennas (UHF) / free-to-air, Direct Satellite (Parabola), and digital broadcast subscriptions. Each of these broadcast technologies can be used depending on the financial capacity of citizens. Electricity problems also become an obstacle for border residents to be able to enjoy Indonesian television broadcasts. Many areas still have problems with electricity supply. Unequal electricity supply in the border area in Meranti Regency is the next obstacle. 
Once in a visit, I accompanied President Jokowi, and he saw the condition of my area, and at the same time, he promised to improve the electricity supply in Meranti. Believe it or not, in Meranti there are still villages that do not have electricity poles, can you imagine an answer if we ask them Nationalism? (Interview: Irwan, 2020).

Nationalism should be positioned equally for all regions and levels of society, in cities and villages. Television becomes a separate point in the social position of individuals in border society. Malaysian television shows also provide mutual understanding among viewers (viewing groups) on the choice model (Webster \& Wakshlag, 1983). The availability of free access to air television Malaysia formed many viewing groups in the border society in the Meranti Regency. They securely watched the broadcast and still presented the same Malay cultural preferences as them.

Broadcasting regulations in Indonesia that should be fully implemented in all border areas, especially in the Meranti Regency so that they can present free-to-air broadcasts in Indonesia, can enjoy easily, and interpretive processes in the border community occur communally. The construction of the meaning of free-to-air technology in Indonesia is easily reached into a framework of understanding collectively on border society can be achieved.

The empirical fact, the condition of social action media studies that occur is the opposite where Indonesian free-to-air television broadcasts are not available on terrestrial technology (UHF). More services must use direct satellite technology, which requires an enormous cost to purchase equipment and installation costs.

Hisam Setiawan, Deputy Chairperson of the Riau Regional Indonesian Broadcasting Commission, explained that there were at least three broadcasting phases in the border region that experienced, namely: the new order phase, the reform phase, and the technology phase.

The New Order phase is the initial phase in border broadcasting where border society has no choice but to enjoy information and entertainment broadcasts from Radio and TV Malaysia. The ability of border society is limited to being able to access Malaysian media broadcasts because Indonesian shows are not yet there (Interview: Hisam, 2019).

The next phase described is the reform phase, where border society in all their limitations begins to have the financial capacity to meet their needs for information from Indonesia by providing satellite dishes placed on their home pages. In the era of satellite dishes, media activities in the border community developed with the presence of subscription broadcasting agency (cable TV) services, which were the answer to the poor quality of Indonesian broadcasts that could be captured with the terrestrial antenna. For this technology, Hisam added that at least border society tend to enjoy television broadcasts through technology, satellite dishes, and UHF antennas into 3, namely:

1. Cultural Broadcast was watching television broadcasts as a form of conformity with the culture adopted. Malay people will tend to enjoy shows that are cultured in Malay. Enjoying soap opera shows from Malaysia that is considered to be of higher quality and 
has cultural values that are close to them and far from Jakarta-Betawi, Jawa, Sunda impression and are more educational than Indonesian soap operas.

2. Entertainment Broadcasts, where light comedy broadcasts from Indonesia are more in demand and show talent search events (dangdut show), also have their attention for border residents.

3. News / Information Releases, where for broadcast information / News, Indonesia television remains a source of reference for their information besides, they also continue to watch information/news broadcasts from Malaysia.

The border society is at the middle and low economic level so that in their daily lives, many still use terrestrial broadcasting technology by utilizing Malaysia's free-to-air broadcast access. Meeting the needs of viewers for information and entertainment broadcasts with a Malay cultural approach that not presented with free-to-air Indonesia broadcasts makes freeto-air Malaysia broadcasts still in demand.

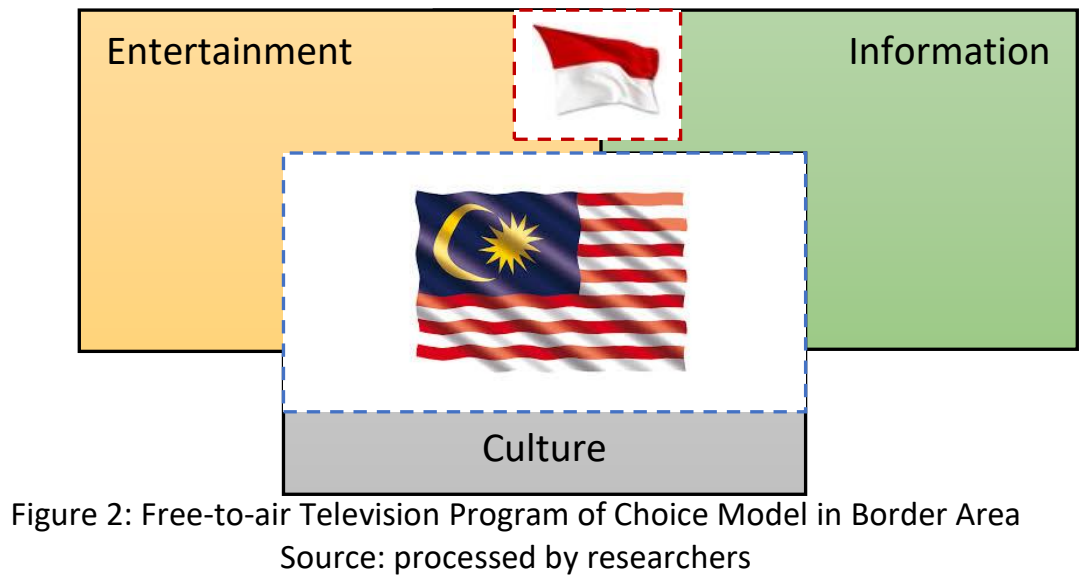

This model sourced from the program of a choice model (Webster \& Wakshlag, 1983; Wonneberger et al., 2009), where the results of the above-processed researchers illustrate that the position of border residents in their activities of watching television closely. With Malaysian free-to-air television because of the ease of use of broadcast technology, namely the use of terrestrial antennas to be able to enjoy the broadcast. The absence of Indonesian television broadcasts on free-to-air services that can reach the border society in the Meranti district makes a significant gradation in access to information.

Besides that, the reality of Malay culture that does not have a place on Indonesian television broadcasts makes border society continue to enjoy Malaysian television broadcasts rather than Indonesian television broadcasts.

I watch Indonesian television if the broadcasts are English premiere league, Moto GP, western films, I am not interested in watching Indonesian television on programs other than that. I prefer Malaysian television broadcasts, which in my opinion, Malaysian shows are more educational and very Malay (Interview: Adam, 2019). 
Border society who watch Indonesian free-to-air broadcasts are also not small but limited to broadcast information, news and talk show that often air on Indonesian television. Even though there are never border society or border conditions being the central review in the activities of Indonesian television reporting. Despite limited access to information through Indonesian television broadcasts, border society is still trying to watch Indonesian television broadcasts using satellite dishes that are not cheap.

The minor side of Nationalism that is present on commercial television in Indonesia. Even though broadcasting regulations have completely stipulated that television stations in Indonesia must provide free-to-air services to all levels of society, but other conditions occur in the border region in Riau province where one of the media groups in Indonesia. Media Nusantara Citra (MNC), which controls RCTI, MNC TV, and Global TV, revoke its broadcast access on digital networks (satellite dish) and cable TV. Their service is only available on freeto-air networks which do not even reach the border society.

This MNC activity that I am worried about will be followed by other media groups such as Trans Corp, Emtek Group, Viva Indonesia. As we know, broadcasting technology has now penetrated internet technology so that if it applied to the border area, it would raise new problems in the ability of border society to access Indonesian television broadcasts on analogue devices. So the border community, especially in Riau, should never be blamed for why they enjoy and love Malaysian television broadcasts more (Interview: Hisam, 2019).

Accessing information needed is something that must be obtained by the viewer. Cheap and easy technology through free broadcasts to air is the answer to these needs. Social action that acts as communal access to free broadcast information to Indonesia. It becomes a complicated and expensive activity carried out with broadcasting agreements that demand equal access to information and broadcasts through free broadcasts for Indonesian television broadcasts that used in wrong interpretations for border society.

\section{Malaysian Broadcasts Are Better, Completely Innoxious}

The Indonesian Broadcasting Commission repeatedly gave a reprimand and not a few of the Indonesian Television programs, which stopped because of adverse and dangerous impacts. Although the regulations that have been prepared by the Indonesian Broadcasting Commission No.01/P/KPI/03/2012 concerning Broadcasting Behavior Guidelines and Broadcast Program Standards (Komisi Penyiaran Indonesia, 2012; Presiden Republik Indonesia, 2002) in Chapter XVII Clause 21 Regarding Classification of Impressions classified into five age-based groups:

Table 5: Classification of Indonesian Television Broadcast Programs by Age

\begin{tabular}{lccc}
\hline NO & Symbol & Broadcast Classification & Target Audience \\
\hline 1 & $\mathrm{P}$ & pre-school children's & $2-6$ Years Old \\
2 & $\mathrm{~A}$ & Children & $7-12$ Years Old \\
3 & $\mathrm{R}$ & A Teenager & $13-17$ Years Old \\
4 & $\mathrm{D}$ & Adults & $>18$ Years Old \\
5 & SU & All Ages & All Ages \\
\hline
\end{tabular}


For border residents who have tried to enjoy Indonesian television shows using satellite dishes that require a hefty fee but served with quality shows that felt to be unsafe for children. Hendri, a young father who is active in social activities every day by establishing many youth societies, feels that Indonesian television broadcasting programs are not safe for his children.

I have bought a satellite dish that is expensive to watch Indonesian broadcasts, but after I installed and watched many Indonesian TV, it did not have good value. For example, soap operas are very dangerous if children watch soap operas because children can imitate the lousy behaviour presented in the soap opera (Interview: Hendri, 2019).

Malaysian cultural broadcasts and television entertainment broadcasts are more in demand, for instance, Malaysian RTM, TV1, TV2, and TV3 broadcasts that broadcast contents with Malay cultural expressions. The cultural expression aired on Malaysian television for border residents is a safe spectacle to be enjoyed by all groups and ages. It is far from the impression of Betawi, Sundanese, and Javanese cultural expressions that dominate Indonesian television broadcasts.

As a precaution, the Riau Regional Indonesian Broadcasting Commission set a target of establishing a local public broadcasting institution managed by the regional government as a container for information on border society.

We have encouraged several local governments to establish public broadcasting institution owned by local governments both radio and television in blank spot areas which will later become a means of conveying information. Connecting the government and maintaining local wisdom withered, but the consequences of regulations with binding government funding sources. We have prepared several opportunities to be able to take administrative leeway to accelerate the licensing of broadcasting institutions, and we have also given a picture of investment opportunities for broadcasting infrastructure in border areas to TV stations in Jakarta. However, they have not received attention (Interview: Falzan, 2019).

The Government of Indonesia, through Government Regulation No. 11 of 2005 (Presiden Republik Indonesia, 2005), has set up the formation of local public broadcasting institutions, which are broadcasters in the form of legal entities established by local governments, organizing radio or television broadcasting activities. They are independent, neutral, not commercial, and functions to provide services for the benefit of the public whose broadcasts networked with Radio Republik Indonesia (RRI) for radio and Televisi Republik Indonesia (TVRI) for television.

Falzan Nurahman, Chairperson of the Riau Regional Indonesian Broadcasting Commission, who was one of the people who had lived in the border region, said that Malaysian television broadcasts were still in demand today. 
I still remember when I was a child, almost all Meranti residents enjoyed Malaysian broadcasts that were present in that era on TV antennas, and we always watched Malaysian shows and enjoyed Malay music and figures that I remembered the most and all Malay people knew who was on our TV when I was a child, P. Ramlee (Interview: Falzan, 2019).

Now, Falzan has become one of the people who regulate and create regulations for the broadcasting industry regulation in Indonesia. According to him, Malaysia's free-to-air broadcasts are still a threat to him in the border region. Warnings because the technology used by border society can capture Malaysian free-to-air broadcasts and other perils because Indonesian free-to-air broadcasts do not apply fairly to border society.

Malaysian TV broadcasts have more value in entertainment and news broadcasts because Indonesian TV broadcasts contain more negative values and high material hegemony. Furthermore, Indonesian TV broadcasts, especially Entertainment such as soap operas, contain a lot of intrigues and negative moral messages compared to Malaysian TV soap opera broadcasts, which are more polite and safer for families to watch. And for News broadcasts, Indonesian TV is more Jakarta and Jawa as overall so that minimal information on other regions, especially border areas and information and TV Indonesia news are considered to contain more negative and prophetic messages. So that the border community has its love for Malaysian broadcasts because it expresses broadcasts that contain local wisdom that has much positive content when viewed (Interview: Falzan, 2019).

Cultural expressions, especially Malay culture, do not have a place on Indonesian free to air broadcasts as an answer to the failure of broadcasting regulations in Indonesia. The spirit of Nationalism in the equality of access to information and containers of cultural expression in the border region is in an unfavourable area of Indonesia. Although it in broadcasting regulations, the industrialization of free to air broadcasts demands the standardization of broadcast content, including certain cultural expressions on Indonesian television broadcasts. So finally the Malay cultural expression in the free to air Malaysia broadcast filled many free to air broadcast slots in the border area.

\section{CONCLUSION}

Study of social action media in response to the failure of the implementation of the Broadcasting Regulations in Indonesia, especially in the aspect of equitable access to information through broadcasting infrastructure, making the collective social action of border communities still love Malaysian free to air television.

Through the Indonesian Broadcasting Commission, the government failed to build broadcasting infrastructure in the border region to serve the information and entertainment needs of border residents. So that border residents still depend on Malaysian free-to-air television broadcasts, and of course, this has an impact on other sectors such as the economy, politics, culture of the border region. 
Indonesian-Malaysian border society in Meranti Regency, Riau Province, is currently living in poverty and uses Malaysian free-to-air television broadcasts because they have the same cultural expression. As border society, Indonesian free-to-air transmissions are unable to meet the need for information, entertainment and then the expression of Malay culture on Indonesian television which had minimal impact on the position of Nationalism was unfavorable for Indonesia. Besides that, Indonesian free-to-air broadcasts in border areas cannot be received well because of Indonesia's uneven broadcasting infrastructure. Access to Malaysian free-to-air television services can meet the border society's needs in their daily social activities. Furthermore, Malaysian free-to-air television broadcasts are considered safe, educational, and provide excellent value for all ages compared to Indonesian free-to-air television broadcasts.

Another thing, the quality of the contents of Indonesian free-to-air television broadcasts felt to be incompatible with the expression of Malay culture where the dominance of the Javanese, Betawi, and Sundanese culture industries on free-to-air Indonesian broadcasts makes Malay culture no place.

\section{ACKNOWLEDGEMENT}

This paper is part of a doctoral project on media studies in the Faculty of Communication Sciences, Universitas Padjadjaran, Bandung-Indonesia. The case study is a part of a dissertation titled "media situation of society who live in the border (a case study of internetbased television technology in the Malay ethnic society in Meranti District, Riau Province)." This research did not receive any specific grants from funding agencies in the public, commercial, or non-profit sectors.

\section{BIODATA}

Harry Setiawan is a PhD candidate at the Faculty of Communication Sciences, Universitas Padjadjaran, Indonesia. Email: harry18001@mail.unpad.ac.id

Siti Karlinah is an Associate Professor in Media Studies at the Faculty of Communication Sciences, Universitas Padjadjaran, Indonesia. Email: siti.karlinah@unpad.ac.id

Dadang Rahmat Hidayat is the Dean of the Faculty of Communication Sciences, Universitas Padjadjaran, Indonesia. Email: dadang.rahmat@unpad.ac.id

Yuliandre Darwis is an Associate Professor in Media Studies at the Faculty of Social Science, Universitas Andalas, and the Commissioner Indonesian Broadcasting Commission. Email: yuliandre.darwis@gmail.com 


\section{REFERENCES}

Abdussalam, S., \& Wahyudi, M. (2016). Principles and strategies of a creative broadcasting program for Indonesian local TV: A descriptive study. Jurnal Komunikasi: Malaysian Journal of Communication, 32(1), 603-627.

Andung, P. A., Sjuchro, D. W., Liliweri, A., \& Hadisiwi, P. (2018a). Posisi media televisi dalam membangun nilai-nilai pada masyarakat perbatasan. Asosiasi Pendidikan IImu Komunikasi (ASPIKOM), 3(5), 917-931.

Andung, P. A., Sjuchro, D. W., Liliweri, A., \& Hadisiwi, P. (2018b). Television as a symbolic culture: A media ethnography study of the border communities of Indonesia - Timor Leste. Teorija in Praksa, 55(2), 328-344.

Awazu, M., Barakat, A. Y., Chevaller, R. L., \& Ichikawa, I. (1989). The cause of uremia in obstructed kidneys. The Journal of Pediatrics, 114(2), 179-186. https://doi.org/10.1016/S0022-3476(89)80781-4

Bagozzi, R. P., \& Dholakia, U. M. (2002). Intentional social action in virtual communities. Journal of Interactive Marketing, 16(2), 2-21. https://doi.org/10.1002/dir.10006

Brosius, H. B., Wober, M., \& Weimann, G. (1992). The loyalty of television viewing: How consistent is TV viewing behaviour?. Journal of Broadcasting \& Electronic Media, 36(3), 321-335. https://doi.org/10.1080/08838159209364180

Bungin, B. (2011). Penelitian kualitatif (Edisi Kedua). Kencana.

Castelfranchi, C. (1998). Modelling social action for Al agents. Artificial Intelligence, 103(1-2), 157-182. https://doi.org/10.1016/s0004-3702(98)00056-3

Dahlan Abdul Ghani. (2015). Upin \& Ipin: Promoting Malaysian culture values through animation. Historia y Comunicación Social, 20(1), 241-258. https://doi.org/10.5209/rev HICS.2015.v20.n1.49558

Denzin, N., \& Giardina, M. (2010). Qualitative inquiry and human rights. Left Coast Press.

Denzin, N. K., \& Lincoln, Y. S. (2009). Handbook of qualitative research. SAGE.

Ellis, D. G., \& Maoz, I. (2003). A communication and cultural codes approach to ethnonational conflict. International Journal of Conflict Management, 14(3/4), 255-272. https://doi.org/10.1108/eb022901

Holmes, D. (2005). Communication theory media, technology and society. SAGE.

Jensen, K. B. (1990). Television futures: A social action methodology for studying Interpretivecommunities. Critical Studies in Mass Communication, 7(2), 129-146. https://doi.org/10.1080/15295039009360169

Juliana Abdul Wahab. (2010). Malaysian reality TV: Between myth and reality. Jurnal Komunikasi: Malaysian Journal of Communication, 26(2), 17-32.

Komisi Penyiaran Indonesia. (2012). Pedoman perilaku penyiaran (P3) dan standar program siaran (SPS) (p. 1-96). KPI Lembaga Negara Independen.

Kriyantono, R. (2008). Teknik praktis riset komunikasi. Kencana.

Littlejhon, S. W., \& Foss, K. A. (2009). Encyclopedia of communication theory. Sage.

Nur Kareelawati Abd Karim, \& Ahmad Fadilah Ahmad. (2018). Religiopolitical and sociocultural factors shaping creative decisions in the production of British and Malaysian Islamic television. Jurnal Komunikasi: Malaysian Journal of Communication, 34(1), 300-315. https://doi.org/10.17576/JKMJC-2018-3401-18

Nur Salawati Mohd Nadzri, \& Hanita Hassan. (2013). The language identities of Malaysians as portrayed in Upin and Ipin. Jurnal Teknologi (Sciences and Engineering), 65(2), 109114. https://sainshumanika.utm.my/index.php/sainshumanika/article/view/105 
Morissan. (2019). The influence of the regulator on television content in post-authoritarian Indonesia. Jurnal Komunikasi: Malaysian Journal of Communication, 35(4), 229-243. https://doi.org/10.17576/JKMJC-2019-3504-14

Peiser, W., \& Peter, J. (2000). Third-person perception of television-viewing behaviour. Journal of Communication, 50(1), 25-45. https://doi.org/10.1111/j.14602466.2000.tb02832.x

Prasojo, Z. H. (2013). Dinamika masyarakat lokal di perbatasan. Walisongo: Jurnal Penelitian Sosial Keagamaan, 21(2), 417-436. https://journal.walisongo.ac.id/index.php/

Presiden Republik Indonesia. (2002). Undang-undang Republik Indonesia nomor 32 tahun 2002 - Tentang penyiaran. KPI Lembaga Negara Independen.

Presiden Republik Indonesia. (2005). Peraturan pemerintah no 11 Tahun 2005 - Tentang penyelenggaraan penyiaran lembanga penyiaran publik. KPI Lembaga Negara Independen.

Renckstorf, K., McQuail, D., \& Jankowski, N. (1996). Media use as social action: A European approach to audience studies (Issue 15 of Acamedia research monographs). John Libbey Eurotext.

Schoening, G. T., \& Anderson, J. A. (1995). Social action media studies: Foundational arguments and common premises. Communication Theory, 5(2), 93-116. https://doi.org/10.1111/j.1468-2885.1995.tb00100.x

Setianto, Y. P. (2015). Media policy in the context of global media flows, the internet, and piracy: An historical analysis of media regulation in Indonesia. Jurnal Komunikasi: Malaysian Journal of Communication, 31(2), 371-388. https://doi.org/10.17576/ikmjc-2015-3102-21

Setiawan, H. (2019). Memiilih diantara 7 tradisi ilmu komunikasi dalam kerangka filosofis. Jurnal Darussalam: Jurnal Pendidikan, Komunikasi dan Pemikiran Hukum Islam, 11(1), 18. https://doi.org/10.30739/darussalam.v11i1.447

Shugart, H. A. (2007). Crossing over: Hybridity and hegemony in the popular media. Communication and Critical/Cultural Studies, 4(2), 37-41. https://doi.org/fkxrc9

Strangelove, M. (2015). POST-TV piracy, cord-cutting, and the future of television. University of Toronto Press.

Sugiyono. (2011). Metode penelitian kuantitatif, kualitatif, dan R\&D. Alfabeta.

Walsh, J. P. (2015). Border theatre and security spectacles: Surveillance, mobility and realitybased television. Crime, Media, Culture: An International Journal, 11(2), 201-221.

Webster, J. G., \& Wakshlag, J. J. (1983). A theory of television program choice. Communication Research, 10(4), 430-446. https://doi.org/10.1177/009365083010004002

Wonneberger, A., Schoenbach, K., \& van Meurs, L. (2009). Dynamics of individual television viewing behaviour: Models, empirical evidence, and a research program. Communication Studies, 60(3), 235-252. https://doi.org/cmw3fk

Yin, R. K. (2003). Case study: Design and method. SAGE.

Yusuf, I. A. (2017). Radio di kawasan perbatasan Indonesia dalam centering the margin. Jurnal IImu Komunikasi, 12(2). https://doi.org/10.24002/jik.v12i2.469 